\author{
Zh.R. Arkenova ${ }^{1}{ }^{*}$, R.A. Abramov ${ }^{2}$ \\ ${ }^{1}$ Karaganda Economic University of Kazpotrebsoyuz \\ ${ }^{2}$ Plekhanov Russian University of Economics \\ larkeniva1975@mail.ru,2abramov.ra@rea.ru \\ ${ }^{1}$ https://orcid.org/0000-0002-3523-5489 \\ ${ }^{2}$ https://orcid.org/0000-0002-1736-5693
}

\title{
The role of research institutes in scientific support of state strategic plans
}

\begin{abstract}
Object: Article determines the main directions and conceptual approaches of research institutions in the framework of scientific support for the methodology of strategic planning in modern conditions.

Methods: The scientific abstraction method supported with information analysis and grouping.

Results: This article discusses current problems and key tasks of modernizing scientific-methodological and information-analytical support for the state strategic management of socio-economic development. Main trends in the evolution of objects and subjects of management in the conditions of digital transformation of the information society are investigated. In addition, this research describes the institutional basis for building and functioning of the strategic planning system of the Republic of Kazakhstan. Also, the article presents a structural diagram of a complex of heterogeneous models of strategic planning of socio-economic development. Project solutions have been proposed to build architecture and develop a prototype computer support system for scenario modeling technology in the development of multi-level strategic solutions for the planning of socio-economic development in the emerging infrastructure of the digital economy.

Conclusions: The study showed the importance and urgency of modernizing the methodological and analytical support of the strategic planning system of the Republic of Kazakhstan, considering the main consequences and requirements for the creation and dissemination of digital technologies in various spheres of society. The most important characteristics of innovative changes in the structure and content of strategic planning tasks, the solution of which relates to the unification of the format of presentation of quantitative and qualitative assessments in the digital environment have been revealed. This can improve the degree of validity and coherence of the planned decisions and regulatory measures developed by the state in the area of planning of socio-economic development and ensuring the national security of the Republic of Kazakhstan.
\end{abstract}

Keywords: research institutes, scientific support, strategic plans, socio-economic development, management processes.

\section{Introduction}

The key direction of public policy, which requires full legislative regulation, is the formation of a system of state strategic planning in the country, which would be adequate to the requirements of today. The world and our own experience show that the successful socio-economic development of the country largely depends on building an effective system of strategic planning. The absence of such an approach leads to the fact that the country is developing in a context of blurred strategic priorities and disunity of economic entities in achieving common goals. Accordingly, mechanisms for concentrating resources on solving medium-and long-term state tasks do not work. First of all, this is due to the country's transition to a long-term development strategy linking the development of the economy, social sphere, civil society, the country's financial system, its demographic, productive, intellectual and resource capabilities with national security objectives within the framework of public administration. This raises the number of questions related to issues of compliance with available reserve in the area of methodology, analytical, and information technology (instrumental) support the design, development, implementation and maintenance of systems and mechanisms of management, technology promotion of these initiatives. It is necessary to clearly understand the degree of solution of applied problems associated with the problems of strategic planning, the nature of possible gaps between the existing logical-cognitive and information-analytical potential of existing automated systems to

\footnotetext{
* Corresponding author.

E-mail address: arkeniva1975@mail.ru
} 
support public administration functions, the tasks they face, as well as the real possibilities of "digitalization" of management processes.

\section{Literature Review}

Mechanisms of scientific justification, analysis of mathematical and instrumental tools used in the system of state strategic planning for justification and analysis, development and adjustment of management decisions to regulate socio-economic development, are sufficiently presented in the scientific literature.

Considering the basics of strategic planning, Belyakov, G.P., Belyakov, S.A., \& Shpak, A.S. (2019) and Borbasova, Z.N., Sedlarskiy, T., Bezler, O.D. (2019) highlight the problems and shortcomings of the system and infrastructure of state strategic planning.

Some scientists note the existence of a peculiar gap in the field of methodological provision of state planning functions (Pupysheva, T.N. (2014), Maass, G. (2013)). The study of publications demonstrates the need to improve the regulatory and methodical, information-analytical and technological support of planning (Mironov, A.V. (2012), Sutherland, K.A. (2018)). It is impossible not to notice the growing discrepancy between the composition and content of management tasks, which are solved at different levels and in different areas of management of the strategic planning system, and the tools used to address them, including previously tested mathematical methods and models.

According to Bolander, K. \& McGrath, C. (2020) the essence of the cause-and-effect approach in the strategic process, according to the author, is to conduct three procedures: 1) full and coordinated consideration of factors that affect the formation of sustainable development problems, risks of socio-economic development and threats to national security at the Federal, sectoral, regional and municipal levels; 2) establishing the relationship and synergy of factors to identify each problem (threat); 3) differentiated, coordinated, consistent and adequate choice of methods for solving problems and eliminating threats, taking into account the variety of factors that create problems and threats and the nature of their manifestation at the appropriate levels.

The current reality raises a whole range of problems, increasingly explored by the scientific community. Summarizing a large number of scientific studies using the example of strategic planning analysis at the meso level (regional level) Analiticheskiy doklad Analiz sistem strategicheskogo planirovaniya i prognozirovaniya Respubliki Belarus, Respubliki Kazakhstan i Rossiyskoy Federatsii (2014). has identified the following problems: 1) insufficient level of methodical support; 2) non-compliance with macroeconomic indicators in planned activities and aggregation of other indicators; 3 ) fragmentation of plans at different levels of government.

The latter is also influenced by changes in the technological order, one of the manifestations of which is the formation of the infrastructure of the information society based on the global spread and changes in the characteristics of communication and computer technology. Therefore, research institutes, due to the development of mathematical apparatus and information and analytical technologies, use these mechanisms to support research and manage socio-economic systems.

\section{Methods}

Strategic planning should be considered by all public authorities and management as a universal tool that provides a systematic and interrelated strategic goal setting, setting and implementing major public tasks using the mechanism of public-private partnership and integrated consideration of a variety of internal and external factors. It is strategic planning that can improve the efficiency and quality of public administration in the harsh conditions of globalization and increase strategic risks to development and threats to national security. A wide range of various sources of official information was processed, including normative legal and strategic policy documents, statistical data, scientific and specialized publications, information and reference materials of international organizations.

\section{Results}

The focus of scientific and methodological support of the strategic planning system as a mechanism of public administration is shifting towards the formation and implementation of unified algorithms for analyzing a huge array of information contained in strategic planning documents, the widespread use of software and mathematical tools for simulating the dynamics of complex socio-economic systems, methods for assessing the state of economic sectors and social spheres, and making management decisions on the choice of optimal development scenarios, to overcome the identified risks and threats. In this regard, it seems appropriate to strengthen the mechanisms for the formation of fundamental and applied research in the field of 
Economics and public administration, creating a scientific and methodological environment for the digital economy, the legal framework for the widespread use of algorithms for "big data" and artificial intelligence technologies in the system of strategic planning for socio-economic development and ensuring national security. It is obvious that the research subject matter is of an interdisciplinary nature with a focus on practical results and the widespread use of IT technologies, which indicates systemic changes in the organization of scientific research, increasing the demands of customers to their results.

\section{Analysis of the use of the project approach in state administration}

In the Republic of Kazakhstan, the practice of applying the project approach in public administration is mainly related to the implementation of state programs.

The rules for the development of state programs were firstly approved in a Decree of the Government of the Republic of Kazakhstan dated January 21, 2003. These rules were developed in order to ensure a unified approach to the development of state programs in the Republic of Kazakhstan and defined organizational and methodological bases, General principles for the formation of state programs, the procedure for their development, approval and approval, as well as monitoring their implementation.

The analysis of the effectiveness of budgetary programmes was carried out in accordance with the Rules for assessing the effectiveness of budget programmes approved by the Government of Kazakhstan on 21 July 2004, which determined the manner in which budget programmes were conducted and assessed in the process of their planning, implementation and internal monitoring of their implementation. According to these rules, the evaluation of the effectiveness of budget programmes was carried out to determine the degree to which the ultimate goal of the programmes is achieved, using criteria of efficiency, timeliness, quality and cost effectiveness.

Peformance assessment is achieved by determining the direct and final outcome of the budget programme administrator. A direct result of the activities of the budget program administrator is a quantitative indicator, characterizing the volume of services provided (performed works) by the administrator of budget programs during the reporting period.

The result of the budget program administrator's activities is a qualitative indicator, characterizing the administrator of budget programs of public policy goals in the budget execution process.

In 2007, these Rules were amended by the decree Of the Government of the Republic of Kazakhstan dated August 20, 2007 on the issues of evaluating the effectiveness of budget programs in internal control over the implementation of budget programs.

It is also noted that during performance control the following are subject of verification:

- execution of measures by deadlines;

- expected results;

- indicators after the completion of the budget programs;

- targeted use of grants;

- guaranteed government loans;

- assessment of the efficiency and productivity of state assets.

The cost-effectiveness assessment refers to the fact that the monitored object has achieved the specified results using the smallest amount of public funds or the best result using the specified amount of public funds when fully implementing the measures provided for in the budget program passport.

Productivity assessment is determined by the ratio between the output of products, the volume of services rendered and other results of the activities of the objects of control and the material, financial, labor and other resources spent on obtaining these results.

The President of the Republic of Kazakhstan on 28 February 2007 in his annual address to the nation "New Kazakhstan in new world" highlighted the important direction of the Government of the Republic of Kazakhstan on building a qualitatively new model of state administration on principles of corporate governance, effectiveness, transparency and accountability.

In order to implement the message of the President of the Republic of Kazakhstan, the Government of Kazakhstan has developed a concept for the implementation of a results-based state planning system.

The aim of the Concept is to develop basic approaches and principles for the gradual formation and implementation of a well-functioning new model of state planning in the Republic of Kazakhstan.

The following objectives are set in order to achieve this goal: 
- Development of new approaches to the development and content of policy documents aimed at increasing the independence of public authorities in decision-making, as well as strengthening their responsibility for the services provided and achieving final results by setting targets (indicators);

- Creating a logical vertical of state planning: strategic development goals of the country-strategic development goals of state bodies - specific tasks-indicators - budget resources;

- Reform of the budget process in order to ensure transparency and public control over the activities of state bodies related to the development and implementation of program documents and their use of budget funds.

The acceptation of the Budget Code was the basis for the transition to results-oriented budgeting.

The introduction of the state planning system allowed:

1) build a hierarchy of state planning documents: form a logical vertical of state planning, identify key areas of economic development and, through decomposition, direct the activities of state bodies to implement strategic objectives;

2) introduce new approaches to the development of program documents aimed at increasing the independence of state bodies, as well as strengthening their responsibility for the development of industries and areas, achieving targets and final results;

3) regulate all state planning processes, implement control over the implementation of documents of the state planning System (monitoring, evaluation);

4) create conditions for effective management of state and other resources in accordance with priorities and strategic objectives.

The stages of the state planning system include development, implementation, monitoring, evaluation and control. Strategic and program documents, strategic plans of state bodies, and territorial development programs are monitored based on the results of monitoring and evaluation.

The next important event in the development of Kazakhstan's public administration was the development of the Concept for the Improvement of the State Planning System, which was approved by the Government of Kazakhstan on August 2, 2013 No. 765. The concept of improving the Results-based Public Planning System is based on a comprehensive analysis of the current state planning system, taking into account international experience, which contains the basic principles and approaches for the further development of the public planning system, as well as defines the objectives and objectives of public policy on public planning.

Public planning is an integral part of effective and effective public administration.

The effectiveness of public administration largely depends on the approach applied. In our opinion, the introduction of a project approach to the system of government helps to improve the efficiency of the implementation of state programs.

By analyzing government planning regulations, the publications of experts and heads of government bodies revealed the following problems:

- Weak legislative regulation of the state planning process;

- Lack of appropriate guidelines on government and socio-economic development programmes;

- Certified project management professionals are not involved in the development and implementation of government programs and projects.

\section{Assessing the effectiveness of government programs and projects}

In order to effectively solve the problems of scientific and methodological support of the strategic planning system as a mechanism of public administration, we consider it appropriate to establish the following definition: "State needs in the field of scientific research - these are the results of search and applied research funded from the Federal or regional budget, expected and used by public authorities for the purpose of directly improving the mechanisms and solving the tasks of public administration in the sphere of competence established in accordance with legal acts, based on the principles of strategic planning." As a result, the functional criteria for the formation of a thematic list of research and applied research in the field of Economics and public administration are to:

the topics of applied research directly correspond to the key objectives of improving governance mechanisms, established the basic strategic planning documents;

- terms of reference, mechanism implementation and results of scientific research directly provided state needs in the sphere of competence of the public authority customer works; 
- the results of scientific research represented a set of new knowledge and practically important information on the subject of research, as well as a necessary and sufficient list of tools and recommendations for the operational use of the results in the practical activities of the customer. The ideal interaction between customer and performer of the research work in the process of the acceptance procedures is the willingness to consolidate the main research results in the format of a plan ("road" maps) measures for their implementation in activities of a customer of works, the preparation of which will be identified and prevented possible implementation risks.

In the Republic of Kazakhstan, the Institute of economic research and the Kazakhstani Institute for strategic studies under the President of the Republic of Kazakhstan play a role in solving the tasks of scientific and methodological support of the strategic planning system.

The Institute of Economic Research has many years of experience in methodological and expert support of the state planning system in the country. The main activities of the Institute of Economic Research of a strategic nature are presented in Figure 1.

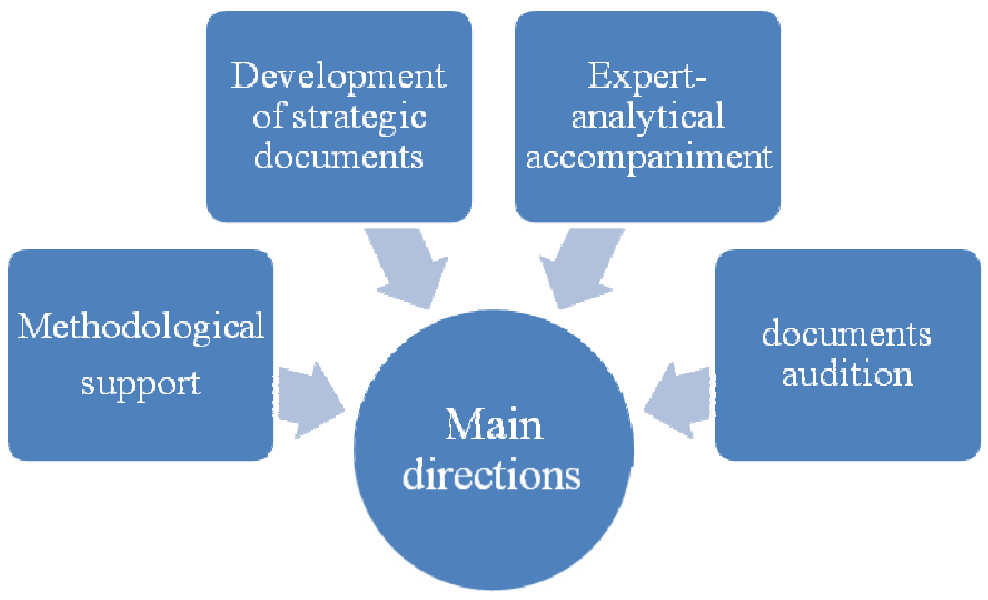

Figure 1. Main activities of the Institute of economic research

Note - compiled by the author on the basis of materials from the Institute of economic research (2020)

According to the Institute of economic research (2020), the main strategic directions include the following projects:

- Methodological support of the state planning system;

- Development of strategic and program documents (Strategic development plan until 2025; Export strategy; Updating of the Forecast scheme of territorial and spatial development of the country; Strategy for the development of the service sector in the Republic of Kazakhstan until 2030);

- Expert and analytical support for improving the monitoring of the implementation of documents of the state planning System (SSP);

- Revision of documents of the SSP (Strategic development plan of the Republic of Kazakhstan, state programs, etc.);

- Expert and analytical support of the implementation of the sustainable development Goals in Kazakhstan (recommendations for integrating the principles, objectives and indicators of the to the documents of state planning System; Assistance to local Executive bodies in the process of localizing the SDGs in the regions; Promotion of community involvement in the implementation of the SDGs).

Scientific justification of strategic documents carried out by the Institute of economic research plays an important role in the sustainable development of the national economy, which is determined not only by the size of the economic effect, but also primarily by the socio-political results of the activities of state bodies.

Expert and analytical support for improving the monitoring of the implementation of documents of the state planning System conducted by the Institute of economic research is necessary for:

- control over the solution of program tasks and achievement of the main planned results of implementation of strategic programs;

- evaluating the effectiveness of budget spending; 
- assessment of the actual contribution of state programs to the socio-economic development of the country;

- improving the efficiency and effectiveness of program implementation.

The success and effectiveness of long-term development strategies, state and regional programs largely depends not only on the quality of development, but also on the mechanisms for their implementation. The implementation of these documents is carried out through the strategic plans of state bodies, strategies and development plans of national holdings and companies, industry programs and, of course, the national and local budgets.

An important role in the sustainable development of the national economy of the country is played by strategic plans of a socio-economic nature, which are formed on the basis of the developed strategic goals of the Strategic development plan of the Republic of Kazakhstan.

The main research activities of the Kazakhstan Institute for strategic studies under the President of the Republic are shown in figure 2.

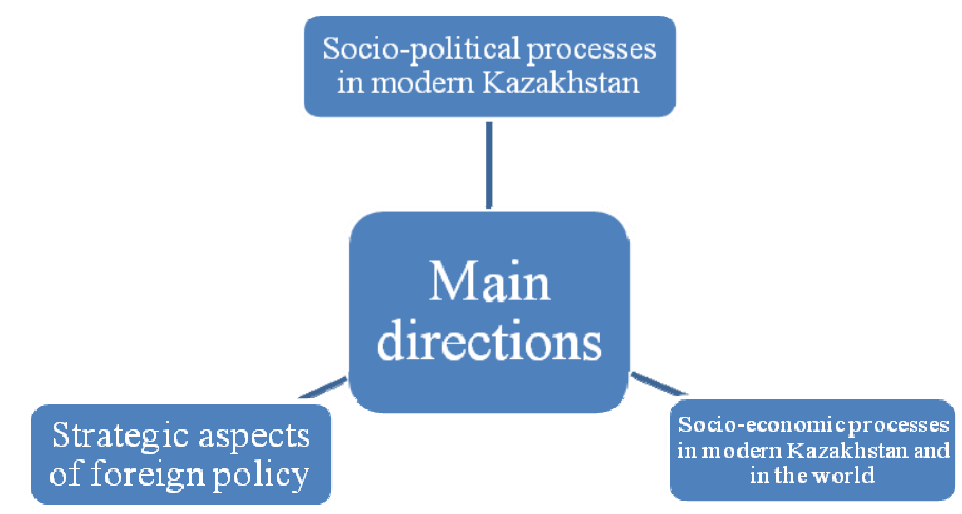

Figure 2. Main research directions of the Kazakhstan Institute for strategic studies under the President of the Republic of Kazakhstan

Note - Compiled by the author based on the materials of the Kazakhstan Institute for strategic studies under the President of the Republic of Kazakhstan (2020)

The main research areas of the Kazakhstan Institute for strategic studies under the President of the Republic of Kazakhstan (2020) include:

- Socio-political processes in modern Kazakhstan: analysis of the current political situation in Kazakhstan, including monitoring of the socio-political situation in the Republic of Kazakhstan; comprehensive research on political and ideological modernization; forecasting and modeling of socio-political processes; analysis of the state of political institutions, interethnic and interfaith relations, issues of countering religious extremism and terrorism; study of current media processes and information trends;

- Socio-economic processes in modern Kazakhstan and the world: research challenges and trends of social development of the Republic of Kazakhstan; monitoring the socio-economic situation in the Republic of Kazakhstan; study of tendencies of development of world economy and the analysis of their impact on the economy of Kazakhstan; analysis of regional development, including the study of the processes of urbanization and migration; study of the problems of economic security of the Republic of Kazakhstan;

- Strategic aspects of foreign policy: monitoring of modern geopolitical vectors and analysis of foreign policy strategies; monitoring of domestic and socio-economic development of neighboring countries; analysis of Kazakhstan's bilateral relations with Russia, China, the United States, Turkey, Central Asian countries, the European Union, the Eurasian Economic Union and the CIS; analysis of integration processes at the regional and global levels; study of international security and peacekeeping efforts of Kazakhstan.

According to the materials of the Kazakhstan Institute for strategic studies under the President of the Republic of Kazakhstan, the scientific justification of the country's strategic plans is due to the need to increase the efficiency of budget expenditures that ensure the structuring of budget expenditures according to the goals and objectives of long-term state policy.

Scientific support of projects carried out by the Kazakhstan Institute for strategic studies under the President of the Republic of Kazakhstan are designed to determine the goals, objectives and tools of state policy aimed at implementing the priorities of the country's strategic development and ensuring national security. 
Summarizing our research, we note that the use of scientific support in the state strategic planning of the Republic of Kazakhstan has its own characteristics. Public administration, based on the scale of activity, is one of the areas that most often faces changes of various kinds. Here, scientific support provided by research institutes can be a so-called "universal technology for effective change management", since the advanced management methodology dictates the presence of constant monitoring for regular adjustments to the plan, its constant refinement and improvement of results. Therefore, in state strategic planning, it is important to focus not only on public policy, but also on scientific support.

\section{Discussion}

The methodology of strategic planning provides for a system of short -, medium-and long-term forecasts of socio-economic development, selection of priorities for technical and economic development, tools and mechanisms for their implementation.

Structuring of already adopted and developed socio-economic development programs is a necessary component of working on the strategy. Their targets and implementation measures should undergo a systematic coordination procedure, which will require evaluating the measure of their resource balance, identifying possible contradictions between targets and economic policy instruments, justifying the requirements for their synchronization, identifying bottlenecks and setting the task of supplementing the existing set of programs with new ones in order to ensure a critical mass of impacts on the course of reproduction processes and minimizing negative system effects.

In this work, the use of balance-based planning methods should be resumed, considering the limited scope and forms of their application determined by market mechanisms. An integral element of the process of developing a socio-economic strategy is forecasting, which should ensure the construction of several coordinated variants of socio-economic policy and scenarios for the development of the Russian economy and on this basis set the task of determining the preferred socio-economic policy. At the same time, a necessary condition for strategic planning is a clear goal setting, including the separation of goals, criteria for the success of development (fundamental goals and second-level goals with measurable macro indicators) and instrumental goals. To complete the strategic planning system, it is necessary to introduce norms of responsibility for achieving the planned results and using the necessary tools of macroeconomic policy. This includes establishing legal norms of economic responsibility of organizations and administrative responsibility of managers for meeting the development targets set by the Government.

\section{Conclusion}

Considering the activities of research institutes, it can be concluded that the scientific support of state strategic planning has the following components:

1) methodological support. The need to improve the methodology of strategic planning, and the impact of digitalization processes on objects and subjects of management at various levels in terms of unification of formats for describing heterogeneous information and standardization of the structure of its processing services creates prerequisites for the modernization of analytical and computer tools for strategic planning;

2) information support. Detailed information of a sociological, technological, economic, environmental and other nature determines the need for the formation of a methodology for building programming complexes and monitoring the development of socio-economic systems at various levels using methods of artificial intelligence technologies;

3) legal support. Legal education of civil servants, formation of their legal awareness of the value of state strategic planning, their awareness of its effectiveness and instrumental suitability in public activities;

4) personnel support. Improving the system of training qualified personnel (analysts) engaged in the field of state strategic planning. Specialists of this profile should be trained purposefully in higher education institutions, as part of the implementation of basic educational programs, as well as professional retraining and advanced training programs.

\section{References}

Analiticheskii doklad «Analiz sistem stratehicheskoho planirovaniia i prohnozirovaniia Respubliki Belarus, Respubliki Kazakhstan i Rossiiskoi Federatsii (2014). [Analytical report Analysis of strategic planning and forecasting systems of the Republic of Belarus, the Republic of Kazakhstan and the Russian Federation]. Departament makroekonomicheskoi politiki Yevraziiskaia ekonomicheskaia komissiia - Macroeconomic Policy Department Eurasian Economic Commission. Moscow [in Russian].

Belyakov, G.P., Belyakov, S.A., \& Shpak, A.S. (2019). Hosudarstvennoe upravleniie nauchno-tekhnolohicheskim razvitiem: zarubezhnyi opyt [State management of scientific and technological development: foreign experience]. 
Voprosy innovatsionnoi ekonomiki - Issues of innovative economy, 3(9), 657-672. DOI: 10.18334/vinec.9.3.40856 [in Russian].

Bolander, K. \& McGrath, C. (2020). Failure as a catalyst for learning: towards deliberate reflection in academic development work. International Journal for Academic Development, 1(25), 1-4 https://doi.org/10.1080/ 1360144X.2020.1717783

Borbasova, Z.N., Sedlarskiy, T., \& Bezler, O.D. (2019). Analiz sovremennoho vzaimodeistviia rynka truda i professionalnoho obrazovaniia Kazakhstana [Analysis of the modern interaction of the labor market and vocational education in Kazakhstan]. Vestnik Karahandinskoho universiteta. Seriia Yekonomika - Bulletin of the Karaganda University. Economy series, 2(94), 98-105 [in Russian].

Bulasheva, A.A., \& Kusainov, T.A. (2019). Otsenka vliianiia investitsii v obrazovanie na razvitie chelovecheskoho kapitala i eho vozdeistvie na ekonomicheskii rost [Assessment of the impact of investment in education on the development of human capital and its impact on economic growth]. Vestnik Karahandinskoho universiteta. Seriia Yekonomika - Bulletin of the Karaganda University. Economy series, 2(94), 41-48 [in Russian].

Dannyye Komiteta po statistike Respubliki Kazakhstan (2018). [Data of the Committee on Statistics of the Republic of Kazakhstan for 2013-2018]. stat.gov.kz. Retrieved from http://www.stat.gov.kz. [in Russian].

Gulbrandsen, M. \& Kyvik, S. (2015). Are the concepts basic research, applied research and experimental development still useful? An empirical investigation among Norwegian academics. Science and Public Policy, 5(37), $343-353$.

Locke, E.A. \& Latham, G.P. (2012). A Building a Practically Useful Theory of Goal Setting and Task Motivation. American Psychologist, 9(57), 705-717.

Maass, G. (2013). Funding of Public Research and Development: Trends and Changes. OECD. Journal on Budgeting, 4(3), 57-66. Retrieved from http://www.oecd.org/gov/budgeting/43494478.pdf.

Mironov, A.V. (2012). Obrazovaniie kak sfera hosudarstvennoi politiki [Education as a public policy sphere]. Sotsialnohumanitarnye znaniia - Social and Humanitarian Knowledge, 6(29), 57-62 [in Russian].

Natsionalnyi doklad po nauke (2018). [National Science Report]. Astana, Almaty. OESR "Kompleksnyi stranovoi obzor Kazakhstana: Chast 1. Predvaritelnaia otsenka. Puti razvitiia OESR (2016). [OECD Kazakhstan Comprehensive Country Review: Part 1. Preliminary Assessment. OECD Development Paths] [in Russian].

Pupysheva, T.N. (2014). Analiz stratehicheskoho planirovaniia deiatelnosti kazakhstanskikh vuzov [Analysis of strategic planning of the activities of Kazakhstani universities]. Proceedings from The scientific community of students of the XXI century. Economic sciences: XVII Mezhdunarodnaia studencheskaia nauchno-prakticheskaia konferentsiia — the XVII international student scientific-practical conference, 2(17), 87-95 [in Russian].

Petrenko, Y.S., \& Koroleva, A.A. (2019). Otsenka obrazovaniia kak faktor razvitiia kreativnoi ekonomiki: marketinhovyi aspekt [Education Assessment as a Factor in the Development of a Creative Economy: Marketing Aspect]. Vestnik Karahandinskoho universiteta. Seriia Yekonomika - Bulletin of the Karaganda University. Economy series, 4(2), 325-329 [in Russian].

Stratehiia 2050 (2012). [Strategy 2050]. Stratehii i prohrammy Respubliki Kazakhstan. Ofitsialnyi sait Prezidenta Respubliki Kazakhstan - Strategies and programs of the Republic of Kazakhstan Official website of the President of the Republic of Kazakhstan. http://www.akorda.kz. [in Russian].

Sutherland, K.A. (2018). Holistic academic development: Is it time to think more broadly about the academic development project? International Journal for Academic Development, 4(23), 261-273.

UNESCO Institute for Statistics (2017). http://data.uis.unesco.org. Wijngaards-de Meij, L., \& Merx, S. (2018). Improving curriculum alignment and achieving learning goals by making the curriculum visible. International Journal for Academic Development, 3(57), 219-231.

Yuvitsa, N.V. (2015). Stratehicheskoe planirovanie i hosudarstvennyi menedzhment Kazakhstana [Strategic planning and state management of Kazakhstan]. Mezhdunarodnyi zhurnal eksperimentalnoho obrazovaniia — International Journal of Experimental Education, 3(2), 247-249 [in Russian].

Zakon Respubliki Kazakhstan "O nauke” (2019). [Law of the Republic of Kazakhstan "On Science”] [in Russian].

Zakon RK "O kommertsializatsii rezultatov nauchnoi i nauchno-tekhnicheskoi deiatelnosti” (2015). [Law of the Republic of Kazakhstan "On the commercialization of the results of scientific and scientific-technical activities"]. No. 381$\mathrm{V}$ [in Russian].

\section{Ж.Р. Аркенова, Р.А. Абрамов}

\section{Мемлекеттік стратегиялық жоспарларды ғылыми қамтамасыз етудегі ғылыми-зерттеу институттарының рөлі}

\footnotetext{
Аңдатпа

Maқ̧cambl: Қазіргі жағдайда стратегиялық жоспарлау әдіснамасын ғылыми қамтамасыз ету аясында ғылыми-зерттеу институттарының негізгі бағыттары мен тұжырымдамалық тәсілдерін анықтау.

Әдісі: Ақпаратты талдау және топтау арқылы көрсетілетін ғылыми абстракция әдісі.

Қорытынды: Мақалада әлеуметтік-экономикалық дамуды мемлекеттік стратегиялық басқаруды ғылымиәдістемелік және ақпараттық-аналитикалық қамтамасыз етуді модернизациялаудың өзекті мәселелері мен
} 
негізгі міндеттері қарастырылған. Ақпараттық қоғамның цифрлық трансформациясы жағдайында басқару объектілері мен субъектілері эволюциясының негізгі тенденциялары зерттелді. Бұдан басқа, осы зерттеуде Қазақстан Республикасының стратегиялық жоспарлау жүйесін құрудың және оның жұмыс істеуінің институционалдық негіздері сипатталды. Мақалада әлеуметтік-экономикалық дамуды стратегиялық жоспарлаудың гетерогенді модельдері кешенінің құрылымдық диаграммасы келтірілген. Цифрлық экономиканың дамып келе жатқан инфрақұрылымы жағдайында әлеуметтік-экономикалық дамуды жоспарлау үшін көп деңгейлі стратегиялық шешімдерді әзірлеу кезінде архитектураны құру және сценарийді модельдеу технологиясын қолдаудың компьютерлік жүйесінің прототипін жасау бойынша жобалық шешімдер ұсынылған.

Тұжырымдама: Жүргізілген зерттеу қоғам өмірінің әртүрлі салаларында цифрлық технологияларды құру мен таратудың негізгі салдарлары мен талаптарын ескере отырып, Қазақстан Республикасының стратегиялық жоспарлау жүйесін әдістемелік және талдамалық қамтамасыз етуді жаңғыртудың маңыздылығы мен өзектілігін көрсетті. Стратегиялық жоспарлау міндеттерінің құрылымы мен мазмұнындағы инновациялық өзгерістердің маңызды сипаттамалары анықталды, олардың шешімі сандық және сапалық бағалауды ұсыну форматын біріздендірумен байланысты. Бұл әлеуметтік-экономикалық дамуды жоспарлау және Қазақстан Республикасының ұлттық қауіпсіздігін қамтамасыз ету саласында мемлекет әзірлейтін, жоспарланатын шешімдер мен нормативтік шаралардың негізділігі мен келісу дәрежесін арттыруға мүмкіндік береді.

Kiлm сөздер: ғылыми-зерттеу институттары, ғылыми қолдау, стратегиялық жоспарлар, әлеуметтікэкономикалық даму, басқару процестері.

\section{Ж.Р. Аркенова, Р.А. Абрамов}

\section{Роль научно-исследовательских институтов в научном обеспечении государственных стратегических планов}

\section{Аннотация}

Цель: Определить основные направления и концептуальные подходы научно-исследовательских институтов в рамках научного обеспечения методологии стратегического планирования в современных условиях.

Meтодbl: Метод научной абстракции, поддерживаемый анализом и группировкой информации.

Pезультаты: В статье рассмотрены актуальные проблемы и ключевые задачи модернизации научнометодического и информационно-аналитического обеспечения государственного стратегического управления социально-экономического развития. Исследованы основные тенденции эволюции объектов и субъектов управления в условиях цифровой трансформации информационного общества. Кроме того, в данном исследовании описаны институциональные основы построения и функционирования системы стратегического планирования Республики Казахстан. Также представлена структурная схема комплекса разнородных моделей стратегического планирования социально-экономического развития. Предложены проектные решения по построению архитектуры и разработке прототипа компьютерной системы поддержки технологии сценарного моделирования при разработке многоуровневых стратегических решений для планирования социально-экономического развития в условиях формирующейся инфраструктуры цифровой экономики.

Bblвoдbl: Проведенное исследование показало важность и актуальность модернизации методического и аналитического обеспечения системы стратегического планирования Республики Казахстан с учетом основных последствий и требований создания и распространения цифровых технологий в различных сферах жизнедеятельности общества. Выявлены важнейшие характеристики инновационных изменений в структуре и содержании задач стратегического планирования, решение которых связано с унификацией формата представления количественных и качественных оценок в цифровой среде. Это позволит повысить степень обоснованности и согласованности планируемых решений и нормативных мер, разрабатываемых государством в области планирования социально-экономического развития и обеспечения национальной безопасности Республики Казахстан.

Ключевые слова: научно-исследовательские институты, научное обеспечение, стратегические планы, социально-экономическое развитие, управленческие процессы.

\section{References}

Bolander K. Failure as a catalyst for learning: towards deliberate reflection in academic development work [Текст] / K. Bolander, C. McGrath // International Journal for Academic Development. — 2020. — Vol. 25, № 1. — P. 1-4. - (https://doi.org/10.1080/1360144X.2020.1717783).

Gulbrandsen M. Are the concepts basic research, applied research and experimental development still useful? An empirical investigation among Norwegian academics [Текст] / M. Gulbrandsen, S. Kyvik // Science and Public Policy. - 2015. - Vol. 37, № 5. - P. 343-353.

Locke E.A. A Building a Practically Useful Theory of Goal Setting and Task Motivation [Tекст] / Е.A. Locke, G.P. Latham // American Psychologist. — 2012. — Vol. 57, № 9. — P. 705-717.

Maass G. Funding of Public Research and Development: Trends and Changes. OECD [Tекст] / G. Maass // Journal on Budgeting. — 2013. — Vol. 3, № 4. — (http://www.oecd.org/gov/ budgeting/43494478.pdf). 
Sutherland K.A. Holistic academic development: Is it time to think more broadly about the academic development project? [Текст] / K.A. Sutherland // International Journal for Academic Development. — 2018. — № 23(4). — P. 261-273.

UNESCO Institute for Statistics (UIS) database. - (http://data.uis.unesco.org 2017).

Wijngaards-de Meij, L. Improving curriculum alignment and achieving learning goals by making the curriculum visible [Текст] / L. Wijngaards-de Meij, S. Merx // Journal International Journal for Academic Development. — 2018. — Vol. 23, №3. - Р. 219-231.

Аналитический доклад «Анализ систем стратегического планирования и прогнозирования Республики Беларусь, Республики Казахстан и Российской Федерации» [Текст] // Департамент макроэкономической политики. Евразийская экономическая комиссия. - М., 2014. - С. 65.

Беляков Г.П. Государственное управление научно-технологическим развитием: зарубежный опыт [Текст] / Г.П. Беляков, С.А. Беляков, А.С. Шпак // Вопросы инновационной экономики. — М., 2019. — Т. 9, № 3. — C. 657-672. - DOI: 10.18334/vinec.9.3.40856.

Борбасова 3.Н. Анализ современного взаимодействия рынка труда и профессионального образования Казахстана [Текст] / 3.Н. Борбасова, Т. Седларский, О.Д. Безлер // Вестн. Караганд. ун-та. Сер. Экономика. - 2019. — № 1(93). - С. 98-105.

Булашева А.А. Оценка влияния инвестиций в образование на развитие человеческого капитала и его воздействие на экономический рост [Текст] / А.А. Булашева, Т.А. Кусаинов // Вестн. Караганд. ун-та. Сер. Экономика. — 2019. — № 1(93). — С. 41-48.

Жашкенова Р.Б. Государственная программа развития образования и науки на 2016-2019 годы [Текст] / Р.Б. Жашкенова, Г. Накипова // Указ Президента Республики Казахстан от 1 марта 2016 года № 205 // Вестн. Караганд. ун-та. — (https://online.zakon.kz/ Document/?doc_id=32372771).

Данные Комитета по статистике Республики Казахстан за 2013-2018 гг. — (http://www.stat.gov.kz).

Миронов А.В. Образование как сфера государственной политики [Текст] / А.В. Миронов // Социальногуманитарные знания. - 2012. - № 5. - С. 29.

Национальный доклад по науке [Текст]. - Астана; Алматы, 2018. - 120 с. «О коммерциализации результатов научной и научно-технической деятельности». Закон Республики Казахстан от 31 октября 2015 года № $381-$ V. — (https://online.zakon.kz/service/doc.aspx?doc_id=31806330). «О науке» [Текст]: Закон Республики Казах-

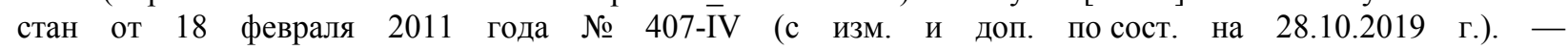
(http://adilet.zan.kz/rus/docs/Z1100000407 ОЭСР)

“Комплексный страновой обзор Казахстана: Ч. 1. Предварительная оценка. Пути развития ОЭСР” [Текст] 2016 г. - (http://www.exclusive.kz/expertiza/politika/13341/).

Петренко Е.С. Оценка образования как фактор развития креативной экономики: маркетинговый аспект [Текст] / Е.С. Петренко, А.А. Королева // Вестн. Караганд. ун-та. Сер. Экономика. — 2019. — № 4(96). — С. 325329.

Пупышева Т.Н. Анализ стратегического планирования деятельности казахстанских вузов [Текст] / Т.Н. Пупышева // Научное сообщество студентов XXI столетия. Экономические науки: сб. ст. по материалам XVII Междунар. студ. науч.-практ. конф. - Новосибирск: Изд. «СибАК», 2014. — № 2(17). — С. 76-85. — (http://sibac.info/archive/economy/2(17).pdf).

Стратегия 2050 [Текст] / Стратегии и программы Республики Казахстан. Официальный сайт Президента Республики Казахстан от 14 декабря 2012 года. — (http://www.akorda.kz).

Стратегическое планирование и государственный менеджмент Казахстана: моногр. [Текст] / Н.В. Ювица // Междунар. журн. эксперимент. образования. - М.: Изд-во НИЦ «Академия естествознания», 2015. — № 3-2. — C. 247-249. — (http://www.expeducation.ru/ru/ article /view? id=6832). 